\section{Censorship in geology?}

SIR - Nature's recent review of Science in India drew attention once more to a Himalayan geological scandal: V. J. Gupta, professor of palaeontology in the department of geology at the Panjab University of Chandigarh, has been accused of scientific fraud carried out over a period of three decades (Nature 366, 616; 1993). The issues were first brought to the attention of a wide audience in 1989 by John Talent of Macquarie University, Australia (Nature 338, 613; 1989). These claims of scientific misconduct have not yet been satisfactorily resolved.

Just before Nature's recent review of Indian science, I had submitted to Elsevier's journal Tectonophysics a solicited book review of The Phanerozoic Geology of the World; The Palaeozoic, A (edited by M. Moullade and A. E. M. Nairn, Elsevier, Amsterdam, 1991). This book contains a lengthy chapter on the Phanerozoic of India, by V. J. Gupta and M. E. Brookfield. It was because of my comments about Gupta that Elsevier decided, in November 1993, against publishing the book review. In their words: "we honestly feel that the section about the Gupta chapter will bring us in the realms of legal implications". My "sensitive" section reads as follows:

In the final analysis of this book, however, the chapter on India requires the sharpest critical focus. India's Palaeozoic rocks are found in three distinct tectonic settings (viz. the High and lesser Himalayas, and cratonic India). The great stratigraphic contrast between the adjacent High Himalaya (formerly part of the northern margin of Gondwana) and lesser Himalaya, has long puzzled geologists, we are told. No real further insight is provided. Rather, what follows is a dour account of fossils and rock types. Most of the focus ( $\sim 65 \%$ of the chapter) is on the High Himalayan sequences, whilst the classic Gondwana formations of the Indian craton are severely underthrust. The reason for this imbalance is because the major Palaeozoic controversies of India are found in the Himalaya; and the first author of this chapter is deeply embroiled in these controversies. Most of these controversies centre on biostratigraphy; Gupta and Brookfield claim that major errors have been made in the past: "These [other] workers claim to have collected all these fossils from a single stratigraphic horizon which, from the list, seem to be unbelievable and unaccept able. A thorough scrutiny of the genera and species recorded by these [other] authors indicates that the fossil identifications seem to have been made without taking any expert opinion on the subject" ( $p$. 95).

The reader is referred to a great list of Gupta's own studies (all coauthored) for more reliable data. Yet this chapter's Gupta is the same Gupta who stands accused of corrupting the palaeontological literature on the Himalayas over the past 30 years or so. The charges laid against Gupta (which include "salting" Himalayan rocks with foreign specimens, "recycling" fossils through different locations, and publishing misleading information about the location of fossil sites) were first made in 1988, and have since been openly debated.

Before submitting my review to Elsevier, I made certain that one of the editors (Nairn) had indeed been made aware of the Gupta affair several years before the book was to appear in print. Clearly the editorial office of Elsevier also knew well in advance of the publication date that Gupta was "on trial". Yet neither the editors (representing the scientific community) nor the publishers (serving the scientific community) were apparently willing to confront this thorny issue of scientific fraud.

From recent discussions at the headquarters of the Geological Society of India in Bangalore, I know that Indian geoscientists are concerned and embarrassed by the "irreparable damage to Indian science" that this saga may cause. B. P. Radhakrishna, president of the society, has also expressed his feeling that the "general silence [of the geoscience community at large] amounting to indifference is disconcerting" (J. Geol. Soc. India 35, 555-558; 1990 \& 34, 561-563; 1989). Publication of this chapter suggests that he is right to feel let down by Western colleagues.

Maarten J. de Wit

Department of Geological Sciences,

University of Cape Town,

Rondebosch 7700 .

South Africa

\section{Balanced board}

SIR - You recently reported that the members of the board of the Danish National Research Foundation are no longer active scientists (Nature 366, 194; 1993). Fortunately this alleged fact is far from reality. Of the nine board members, six are indeed active scientists. In addition, two members, although not personally active in the laboratory, are responsible for extensive research activities The balance on the present board between researchers and research administrators reflects the intentions of the Danish parliament when it created the foundation.

The board of the foundation looks forward with confidence to the evaluation of its activities scheduled for 1997.

\section{Peder Olesen Larsen}

(Chairman of the Board)

Danish National Research Foundation, DK-2900 Hellerup.

Denmark
Shifting sands

SIR - F. J. Leavitt ${ }^{1}$ asks four questions about sand movement. Only one, on the source of the sand in northern Sinai and Israel, can be answered convincingly.

The coastal sands in the northern Sinai and the Israeli coastal plain were shown in 1950 by $\mathrm{Rim}^{2}$ (and subsequently confirmed by others), to derive from the submerged Nile delta, whence it is carried by longshore currents to the Mediterranean coast. The sand reaching the Sinai and Israeli coasts is eventually blown onto the beaches and inland. Most of it becomes arranged into transverse dunes and dune ridges, which have become a prominent feature of the coastal plain. Further inland, it changes into longitudinal (seif) dunes due to the strongly seasonal bidirectional winds ${ }^{3,4}$. Seifs advance slowly by elongation at the dune front, without covering the interdune areas, and may even contain saline sebkhas when the water table is high. Palms and other vegetation in the interdune area thus remain uncovered because of the way in which the seif dunes advance. Because the bidirectional winds are not of equal strength, lateral movement of the sand body is very slow, leaving the interdune area uncovered for a long time.

Bushes and other plants in the interdune area have no special effect on deflecting the wind. If a structure is rather open they reduce the wind speed, and any sand carried will then be deposited in the wind shadow, on the lee side of the plants. When the obstacle is dense or compact, like a wall or plastic screen, the sand will accumulate in front of the structure and eventually cover it. On the basis of this simple principle, various devices have been designed and constructed to protect roads, railways, buildings and so on ${ }^{5}$. The best protection, of course, is to prevent sand movement at source, but this may be difficult or uneconomic, or, in the case of the Mediterranean coast, practically impossible.

The final question on what kind of ecological changes the control of windblown sand may bring about is very broad. Obviously man's interference or control of sand movement is not always beneficial or, rather, the results may be beneficial at one spot but detrimental elsewhere. In general, each system and project must be dealt with on its own merit.

\section{Dan H. Yaalon}

Institute of Earth Sciences,

Hebrew University,

Givat Ram Campus,

Jerusalem 91904, Israel

1. Nature 366, 198 (1993)

2. Israel Exploration J., 1, 20-33(1951)

3. Tsoar, H. Z. Geomorh. Supp/ Bd. 20, 41-61 (1974)

Sedimentology 30, 567-578(1983).

5. Techniques for Desert Reclamation (ed. Goudie, A. S.) (Wiley, New York, 1990). 